\title{
Hydroxyl radical mediated DNA base modification by manmade mineral fibres
}

\author{
P LEANDERSON, ${ }^{12}$ P SÖDERKVIST, ${ }^{3}$ C TAGESSON ${ }^{12}$ \\ From the Departments of Occupational Medicine ${ }^{1}$ and Clinical Chemistry, ${ }^{2}$ University Hospital, S-581 85 \\ Linköping, and Department of Medical Nutrition, ${ }^{3}$ Karolinska Institute, Huddinge University Hospital, F-69, \\ S-141 86 Huddinge, Sweden
}

ABSTRACT Manmade mineral fibres (MMMFs) were examined for their ability to hydroxylate 2deoxyguanosine $(\mathrm{dG})$ to 8 -hydroxydeoxyguanosine $(8-\mathrm{OH}-\mathrm{dG})$, a reaction that is mediated by hydroxyl radicals. It appeared that (1) catalase and the hydroxyl radical scavengers, dimethylsulphoxide and sodium benzoate, inhibited the hydroxylation, whereas $\mathrm{Fe}^{2+}$ and $\mathrm{H}_{2} \mathrm{O}_{2}$ potentiated it; (2) pretreatment of MMMFs with the iron chelator, deferoxamine, or with extensive heat $\left(200-400^{\circ} \mathrm{C}\right)$, attenuated the hydroxylation; (3) the hydroxylation obtained by various MMMFs varied considerably; (4) there was no apparent correlation between the hydroxylation and the surface area of different MMMFs, although increasing the surface area of a fibre by crushing it increased its hydroxylating capacity; and (5) there was good correlation between the hydroxylation of $\mathrm{dG}$ residues in DNA and the hydroxylation of pure $\mathrm{dG}$ in solution for the 16 different MMMFs investigated. These findings indicate that MMMFs cause a hydroxyl radical mediated DNA base modification in vitro and that there is considerable variation in the reactivity of different fibre species. The DNA modifying ability seems to depend on physical or chemical characteristics, or both, of the fibre.

Epidemiological studies have indicated an increased risk of lung cancer associated with occupational exposure to manmade mineral fibres (MMMFs). ${ }^{12}$ Animal studies with glass fibre and other MMMFs have indicated that these minerals are carcinogenic ${ }^{3-5}$ and in vitro experiments have shown that glass fibres as well as asbestos may cause chromosomal aberrations, ${ }^{6}$ morphological transformations, ${ }^{7}$ and chromosomal abnormalities ${ }^{8}$ in cultured cells. Recently, the International Agency for Research on Cancer classified glasswool, rockwool, slagwool, and ceramic fibres as possibly carcinogenic to man.'

The underlying molecular mechanism for MMMF induced carcinogenesis has not been resolved. One possibility is that reactive oxygen species-for example, hydroxyl radicals $\left(\mathrm{OH}^{*}\right)$-are implicated in the carcinogenic process. Hydroxyl radicals are implicated in several harmful processes, including DNA base modifications, ${ }^{10}$ lipid peroxidation, single strand breaks in DNA, and carcinogenesis. " Asbestos fibres catalyse the formation of hydroxyl radicals and superoxide anions $\left(\mathrm{O}_{\dot{2}}\right)$ in a cell free system containing $\mathrm{H}_{2} \mathrm{O}_{2},{ }^{12}{ }^{13}$ and using electron spin resonance; this has also been shown for glass fibres. ${ }^{14}$ With the same technique, asbestos ${ }^{15}$ and rockwool and glasswool ${ }^{16}$

Accepted 16 January 1989 may produce hydroxyl radicals in a cell free system without any addition of hydrogen peroxide.

We have previously reported that certain MMMFs and asbestos fibres may produce hydroxyl radicals that modify hydroxylate 2-deoxyguanosine $(\mathrm{dG})^{17}$ and calf thymus DNA ${ }^{18}$ in a cell free system. In the present investigation we have extended our studies and examined a variety of MMMFs for their ability to hydroxylate DNA - that is, dG residues in DNAand pure $d G$ in solution. The results indicate that there is a large variation between different MMMFs in their DNA hydroxylation and that this variation is caused by differences in chemical or physical properties, or both, of the fibre surface.

\section{Materials and methods}

\section{CHEMICALS}

Calf thymus DNA (type I), nuclease $P_{1}$ from Penicillium citrinum, Escherichia coli alkaline phosphatase (type III), and catalase were obtained from Sigma Chemical Co, St Louis, MO, USA; 2'-deoxyguanosine (research grade) from Serva Feinbiochemica GMBH \& Co, Heidelberg, FRG; iron(II) chloride $\left(\mathrm{FeCl}_{2}\right)$ from Aldrich-Chemie, Steinheim, FRG; dimethylsulphoxide (DMSO, pro analysi) from Riedel-de Haan AG, Seelze, FRG; sodium benzoate and perhydrol 
$\left(\mathrm{H}_{2} \mathrm{O}_{2}\right)$ (pro analysi) from Merck, Darmstadt, FRG; deferoxamine (Desferal) from CIBA-GEIGY, Basle, Switzerland; and phosphate buffered saline (PBS, Dulbecco's medium, modified) from Flow Laboratories, Irvine, UK. 8-Hydroxydeoxyguanosine (8-OHdG) was synthesised in our laboratory according to the method described by Kasai and Nishimura. ${ }^{19}$

FIBRE SAMPLES

Sixteen different types of MMMFs from European plants were provided by $\mathrm{Mr}$ Ingemar Öhberg, Rockwool Inc, Skövde, Sweden. Determination of the surface area of these fibres was carried out on a FlowSorb II 2300, from Micromeritics, Norcross, Georgia, USA, and based on gas desorption with single point measurements using a gas mixture containing helium $(70 \%)$ and nitrogen $(30 \%) .{ }^{20}$ The coefficient of variation in the determination of the fibre area was $\pm 5 \%$.

\section{EXPERIMENTAL SYSTEMS}

The fibres were investigated with regard to their ability to hydroxylate dG residues in calf thymus DNA and pure $\mathrm{dG}$ in solution. The reaction mixtures contained $10 \mathrm{mg}$ fibre and $1.0 \mathrm{ml}$ PBS with $0.5 \mathrm{mg}$ DNA or 0.5 $\mathrm{mM} \mathrm{dG}$. Where indicated, the reaction mixtures were supplemented with additives known to influence the generation of hydroxyl radicals: $\mathrm{FeCl}_{2}(3$ and $30 \mu \mathrm{M})$, $\mathrm{H}_{2} \mathrm{O}_{2}(100 \mu \mathrm{M}$ and $1 \mathrm{mM})$, sodium benzoate (10 and $100 \mathrm{mM})$, DMSO (10 and $100 \mathrm{mM})$, or catalase $(500$ Sigma units $/ \mathrm{ml}$ ). To compare the hydroxylating properties of the different fibres the fibre DNA or fibre $\mathrm{dG}$ mixtures were incubated (in the dark) for five hours in a shaking waterbath at $37^{\circ} \mathrm{C}$. In other experiments fibres were crushed in a glass mortar and fibre DNA mixtures were incubated for one hour at $37^{\circ} \mathrm{C}$ in small polypropylene tubes on a rotator at slow speed. In one series of experiments the fibres were preheated $\left(200^{\circ} \mathrm{C}\right.$ or $\left.400^{\circ} \mathrm{C}, 1 \mathrm{~h}\right)$ in air or oxygen atmosphere (fibres were crushed and placed on a watch glass at the botton of an oven) or pretreated with deferoxamine as described by Weitzman and Weitberg. ${ }^{21}$

After incubation, the amount of 8-OH-dG in the medium was determined, either directly (fibre dG system) or after digestion of DNA (fibre DNA system). In the latter case the ratio between $8-\mathrm{OH}-\mathrm{dG}$ and dG was used to measure the DNA damage. After incubation, the fibres were pelletted and supernatants were extracted with $3.0 \mathrm{ml}$ chloroform: isoamylalcohol (24:1), and centrifuged ( $2000 \mathrm{~g}, 6 \mathrm{~min})$. The upper aqueous phase containing DNA was collected and organic solvents in the aqueous layer were evaporated under a stream of nitrogen. After the addition of $100 \mu \mathrm{l}$ $3 \mathrm{M}$ sodium acetate $\mathrm{pH} 5 \cdot 2$, the DNA was precipitated with 2 vol $70 \%$ ice cold ethanol, centrifuged, washed once with $70 \%$ ethanol, dried, and redissolved in $50 \mu \mathrm{l}$
Leanderson, Söderkvist, Tagesson $\frac{\underline{m}}{\bar{c}}$

$0 \cdot 10$ sodium acetate buffer, $\mathrm{pH} 4 \cdot 8$. The DNA was digested at $37^{\circ} \mathrm{C}$ in a water bath with nuclease $P_{1}$ for 30 minutes and alkaline phosphatase for one hour (the pH was raised from 4.8 to 7.5 by addition of $1.0 \mathrm{M} \overrightarrow{\text { ले }}$ Tris- $\mathrm{HCl}, \mathrm{pH} 8.0$, before treatment with alkaline phosphatase). The amounts of $8-\mathrm{OH}-\mathrm{dG}$ and dG were then determined.

\section{ANALYSIS}

8-OH-dG and dG were analysed with the HPLC technique originally described by Floyd et al..$^{22}$ The $\overrightarrow{0}$ analysis was performed with a Jasco 880-PU HPLCpump and a Jasco 875 ultraviolet spectrophotometric $\omega_{\overparen{D}}$ detector from Japan Spectroscopic Co, Tokyo, Japan. $\mathrm{O}$ An electrochemical detector, Zäta $4 \mathrm{C}$ from Zäta ${ }_{3}^{\mathbb{D}}$ Electronic, Lund, Sweden, was coupled in line with the ultraviolet detector. This detector worked at $254 \mathrm{~nm}$ ? and the EC detector was run in the oxidative mode, $;$ $+0.600 \mathrm{~V}$. Twenty microlitres of the reaction mixture was injected into a Rheodyne 7125 syringe loadingo sample injector (Berkeley, CA, USA) and separated on an Apex Octadecyl $C_{18}$ column $(3 \mu \mathrm{m}, 150 \times 4 \cdot 8 \mathrm{c}$ $\mathrm{mm}$ Jones Chromatography, Mid Glam, UK). The mobile phase consisted of $15 \%$ aqueous methanol $\vec{\circ}$ containing $12.5 \mathrm{mM}$ citric acid, $25 \mathrm{mM}$ sodium $\%$ acetate, $30 \mathrm{mM}$ sodium hydroxide, and $10 \mathrm{mM}$ acetic acid. The flow rate was $1.0 \mathrm{ml} / \mathrm{min}$.

\section{Results}

Table 1 illustrates the hydroxylation of $\mathrm{dG}$ residues in $\mathbb{D}$ DNA caused by a MMMF and the influence of various agents known to affect the generation of 3 reactive oxygen metabolites on this hydroxylation. Catalase inhibited the hydroxylation (heat treatedo enzyme did not) and so did the hydroxyl radica $\overline{5}$ scavengers, sodium benzoate and dimethyl sulphox $\frac{\mathbb{D}}{3}$

Table 1 Influence of various additives on $M M M F$ mediated hydroxylation of $d G$ residues in DNA. Mixtures were incubated for one hour and the amount of 8-OH-dG in DNA determined. The hydroxylation in control incubations (without any fibres) amounted to $5 \cdot 18-\mathrm{OH}-d \mathrm{G}$ residues $/ 10^{5}$ $d G$ and was subtracted throughout. (Means $\pm S D$ of four experiments)

\begin{tabular}{|c|c|c|c|}
\hline Experimental system & \multicolumn{3}{|c|}{ Hydroxylation $\left(8-\mathrm{OH}-d G / 10^{5} d G\right)$} \\
\hline 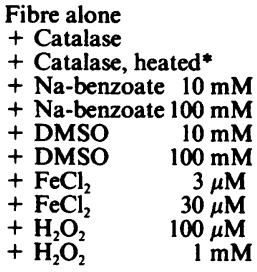 & $\begin{array}{r}4.2 \pm 0.2 \\
0.2 \pm 0.3 \\
4.2 \pm 0.4 \\
2.8 \pm 0.9 \\
2.3 \pm 0.8 \\
2.0 \pm 0.5 \\
0.9 \pm 0.1 \\
7.3 \pm 0.8 \\
17.2 \pm 0.3 \\
11.3 \pm 1.3 \\
26.5 \pm 1.1\end{array}$ & $\begin{array}{r}100 \\
4 \\
100 \\
68 \\
54 \\
48 \\
22 \\
175 \\
410 \\
270 \\
630\end{array}$ & $(\%)$ \\
\hline
\end{tabular}

*Boiled for five minutes. 
Table 2 Hydroxylation of $d G$ residues in DNA (DNA hydroxylation) and of $d G$ in solution (dG hydroxylation) by 16 different MMMFs ( $\mathrm{g}=$ glasswool, $c=$ ceramic fibre, $s=$ slagwool, and $r=$ rockwool). The DNA hydroxylation was assessed as number of $8-O H-d G$ residues $/ 10^{5} d G$, whereas the $d G$ hydroxylation was determined and normalised to that in control incubations (the 8-OH-dG formation formed in incubations without fibres was set to 1). (Means $\pm S D$ of three experiments)

\begin{tabular}{|c|c|c|c|}
\hline Fibre (type) & $\begin{array}{l}\text { Surface area } \\
\left(m^{2} / g\right)\end{array}$ & $\begin{array}{l}D N A \\
\text { hydroxylation }\end{array}$ & $\begin{array}{l}d G \\
\text { Hydroxylation }\end{array}$ \\
\hline $\begin{array}{cc}1 & (\mathrm{c}) \\
2 & (\mathrm{~g}) \\
3 & (\mathrm{c}) \\
4 & (\mathrm{r}) \\
5 & (\mathrm{r}) \\
6 & (\mathrm{r}) \\
7 & (\mathrm{r}) \\
8 & (\mathrm{r}) \\
9 & (\mathrm{r}) \\
10 & (\mathrm{r}) \\
11 & (\mathrm{r}) \\
12 & (\mathrm{~s}) \\
13 & (\mathrm{r}) \\
14 & (\mathrm{r}) \\
15 & (\mathrm{~s}) \\
16 & (\mathrm{r})\end{array}$ & $\begin{array}{l}0.95 \\
0.91 \\
1 \cdot 10 \\
1.30 \\
0.36 \\
0.60 \\
0.73 \\
1.01 \\
1 \cdot 28 \\
1 \cdot 16 \\
1 \cdot 18 \\
1 \cdot 14 \\
1 \cdot 30 \\
1.06 \\
0.90 \\
0.62\end{array}$ & $\begin{array}{l}0.6 \pm 0.1 \\
0.1 \pm 0.1 \\
0.6 \pm 0.2 \\
0.7 \pm 0.1 \\
0.3 \pm 0.1 \\
1.5 \pm 0.6 \\
4.5 \pm 0.5 \\
1.7 \pm 0.3 \\
3.8 \pm 2.6 \\
4.3 \pm 0.3 \\
3.3 \pm 0.5 \\
2.5 \pm 0.9 \\
5.0 \pm 1.0 \\
3.9 \pm 0.5 \\
9.0 \pm 1.1 \\
7.4 \pm 1.6\end{array}$ & $\begin{array}{r}2.1 \pm 0.1 \\
2.9 \pm 1.6 \\
3.0 \pm 0.9 \\
6.4 \pm 2.2 \\
6.4 \pm 2.8 \\
7.8 \pm 0.9 \\
8.1 \pm 2.1 \\
8.4 \pm 0.9 \\
9.7 \pm 0.6 \\
9.8 \pm 1.2 \\
14.5 \pm 1.5 \\
17.1 \pm 1.9 \\
18.4 \pm 3.1 \\
28.2 \pm 6.5 \\
29.3 \pm 1.1 \\
39.2 \pm 2.0\end{array}$ \\
\hline
\end{tabular}

ide. On the other hand, $\mathrm{FeCl}_{2}$ and $\mathrm{H}_{2} \mathrm{O}_{2}$ potentiated the hydroxylation. Heat treatment of the fibres, particularly in an oxygen rich atmosphere, reduced their ability to hydroxylate DNA: fibres heated at $200^{\circ} \mathrm{C}$ and $400^{\circ} \mathrm{C}$ in air for one hour caused only $76 \%$ and $19 \%$, respectively, of the hydroxylation by untreated fibres, whereas corresponding value for fibres treated at $400^{\circ} \mathrm{C}$ in oxygen was $7 \%$ (mean of six experiments). Furthermore, pretreatment of the fibres with deferoxamine reduced the hydroxylation by $29 \%$ (mean of six experiments).

Table 2 shows the hydroxylation of $\mathrm{dG}$ residues in calf thymus DNA and pure dG in solution by 16 different MMMFs. All the fibres caused significant hydroxylation, although the extent of hydroxylation varied considerably. Fibres containing little or no iron-for example, glasswool and ceramic fibreswere poor in their hydroxylating capacity.

There was good correlation between the hydroxyla-

Table 3 Relation between a mineral fibre's surface area and its ability to hydroxylate $d G$ residues in DNA. Fibres (rockwool, No 13 of table 2) were crushed in a mortar for different periods $(0,30$, and $60 \mathrm{sec})$, incubated with calf thymus DNA for one hour, and the amount of $8-O H-d G$ determined. The hydroxylation in control incubations (without any fibres) was subtracted. (Means $\pm S D$ of four experiments)

\begin{tabular}{lll}
\hline Treatment & $\begin{array}{l}\text { Surface area } \\
\left(\mathrm{m}^{2} / g\right)\end{array}$ & $\begin{array}{l}\text { Hydroxylation } \\
\left(8-O H-d G / 10^{5} d G\right)\end{array}$ \\
\hline Uncrushed & $0.6 \pm 0.1$ & $1.4 \pm 0.2$ \\
Crushed for 30 seconds & $0.9 \pm 0.1$ & $3.2 \pm 0.4$ \\
Crushed for 60 seconds & $1.3 \pm 0.1$ & $4.6 \pm 0.3$ \\
\hline
\end{tabular}

tion of $d G$ residues in DNA and the hydroxylation of dG in solution $(r=0.83, p<0.01$, Students $t$ test, $B=$ $0)$. By contrast, there was no apparent correlation between the hydroxylation and the surface area of the different fibres $(r=0.02)$. If the surface area of a fibre was increased by crushing, however, the hydroxylating capacity of that specific fibre was increased (table 3).

\section{Discussion}

Our results show that MMMFs can catalyse the formation of hydroxyl radicals. Hydroxyl radical scavengers added to the incubation mixture decreased the hydroxylation, whereas compounds known to increase the formation of hydroxyl radicals had the opposite effect. The findings also show that MMMFs can hydroxylate DNA in vitro. Such a hydroxylation has been shown for asbestos fibres, ${ }^{23}$ and Zalma et al have suggested that asbestos fibres may cause the formation of reactive hydroxyl radicals by reducing oxygen ${ }^{15}$ according to:

$$
\mathrm{O}_{2} \stackrel{\mathrm{e}^{-}}{\longrightarrow} \mathrm{O}_{2}^{-}
$$

$$
\mathrm{O}_{2}^{-} \stackrel{\mathrm{e}^{-}, 2 \mathrm{H}^{+}}{\longrightarrow} \mathrm{H}_{2} \mathrm{O}_{2}
$$

(3) $\mathrm{H}_{2} \mathrm{O}_{2}+$ (fibre) $-\mathrm{Fe}^{2+} \longrightarrow \mathrm{OH}^{+}+\mathrm{OH}^{-}+($fibre $)-\mathrm{Fe}^{3+}$

The amounts of $\mathrm{O}_{\overline{1}}^{-}$and $\mathrm{OH}^{\circ}$ seemed dependent on the presence of electron donor sites of the minerals: some of the fibres were active in forming hydroxyl radicals whereas others were poor in this respect. Asbestos fibres have been shown to decompose hydrogen peroxide with subsequent formation of hydroxyl radicals. ${ }^{12}{ }^{13}$ We did not add any hydrogen peroxide to the reaction mixture but this component could have been formed according to reactions (1) and (2) above. When catalase was added, the hydroxylation vanished. This goes in line with the results of Zalma et al who found a decreased hydroxyl radical formation when catalase was added to an asbestos solution. ${ }^{15}$

To investigate the mechanisms behind the hydroxyl radical generation further, we examined different types of pretreated fibres. When the fibres were heated before incubation with DNA, the hydroxylation decreased. This could have been due to oxidation of the fibre surface, a possibility that is consistent with the observation that the hydroxylating capacity almost disappeared when the fibres were placed in an oxygen gas flow during the heat treatment. A similar phenomenon has been shown for chrysotile asbestos, whose cytotoxicity towards cultured human fibroblasts and bovine alveolar macrophages was reduced after heat treatment. ${ }^{24}$ Fibres pretreated with the iron chelator, deferoxamine, showed a reduced ability to hydroxylate DNA. Deferoxamine has been shown to decrease asbestos mediated lipid peroxidation ${ }^{21}$ and glassfibre mediated formation of hydroxyl radicals. ${ }^{14}$ 
The iron content of the fibre examined in our study was approximately $5 \%$, which thus seems to have contributed significantly to the formation of hydroxyl radicals.

When a larger number of different fibres was investigated, there were great differences in the hydroxylation, both of dG residues in DNA and of dG in solution. There was, however, a good correlation between the hydroxylation of $\mathrm{dG}$ residues in DNA and of $\mathrm{dG}$ in solution. This points to the possibility of using the more simple dG hydroxylation test for estimating the DNA damaging capacity of different MMMFs.

Our results thus indicate that MMMFs are able to reduce oxygen with the subsequent formation of hydroxyl radicals. These radicals may then cause hydroxylation of DNA and formation of oxidative DNA adducts including 8-OH-dG. It is tempting to speculate that this might play a part in the carcinogenicity of MMMFs. If 8-OH-dG is incorporated in a synthetic oligonucleotide this results in misreading during replication, not only at the $8-\mathrm{OH}-\mathrm{dG}$ residue itself but also at bases next to the 8-OH-dG.$^{25}$ When an oxygen atom is inserted at the C-8 position of a guanine base, this entirely changes the electrostatic potential of the molecule, a factor that could affect the action of DNA polymerase. ${ }^{26}$ Moreover, although in vivo experiments with irradiated mice have indicated the presence of a repair mechanism for removing 8$\mathrm{OH}$-dG from DNA, ${ }^{10}$ this removal was not complete. It may be hypothesised, therefore, that this type of DNA base modification may underlie MMF induced mutation and carcinogenesis.

We thank Olav Axelson for valuable support and acknowledge gratefully the skilled technical help of Anna-Lena Sääf. PS is grateful to the Swedish Natural Science Research Council for a research fellowship. This work was supported by the Swedish Work Environment Fund (87/0898).

\section{References}

1 Saracci R, Simonato L, Acheson ED, et al. Mortality and incidence of cancer of workers in the man made vitreous fibres producing industry: an international investigation at 13 European plants. Br J Ind Med 1984;41:425-36.

2 Enterline PE, Marsh GM. The health of workers in the MMMF industry. In: Biological effects of man made mineral fibres. Proceedings of a WHO/IARC Conference, Copenhagen, 1982. Copenhagen, World Health Organisation, 1984:311-39.

3 Stanton MF, Layard M, Tegeris A, et al. Relation of particle dimension to carcinogenicity in amphibole asbestos and other fibrous minerals. J Natl Cancer Inst 1981;67:965-75.

4 Pott F, Schlipkter HW, Ziem U, Spurny K, Huth F. New results from implantation experiments with mineral fibres. In: Guthe T, ed. Biological effects of man made mineral fibres. Proceedings of a WHO/IARC Conference, Copenhagen, 1982. Copenhagen, World Health Organisation, 1984:286-302.

5 Wagner JC, Berry GB, Hill RJ, Munday DE, Skidmore JW. Animal experiments with $M M M(V) F$ fibres. Effects of inhala-
Leanderson, Söderkvist, Tagessoon

tion and intrapleural inoculation in rats. In: Guthe $T$, ef. Biological effects of man made mineral fibres. Proceedings of 3 WHO/IARC Conference, Copenhagen, 1982. Copenhagen? World Health Organisation, 1984:209-34.

6 Sincock AM, Delhanty JDA, Casey GA. Comparison of the cytogenetic response to asbestos and glass fibre in Chinese hamster and human cell lines. Mutat Res 1982;101:257-68.

7 Hesterberg TW, Barrett JC. Dependence of asbestos and minera $\bar{\Phi}$ dust in transformation of mammalian cells in culture on fibrê. dimension. Cancer Res 1984;44:2170-80.

8 Oshimura M, Hesterberg TW, Tsutsui T, Barrett JC. Correlatio of asbestos induced cytogenetic effects with cell transformatio of Syrian hamster embryo cells in culture. Cancer Res 1984;44: 5017-22.

9 International Agency for Research on Cancer. Monograph on the evaluation of the carcinogenic risk of chemicals to humans. Vod 43, Man made mineral fibres. Lyon: IARC, 1988.

10 Kasai H, Crain PF, Kuchino Y, Nishimura S, Ootsuyama A Tanooka $\mathrm{H}$. Formation of 8-hydroxyguanine moiety in cellulas DNA by agents producing oxygen radicals and evidence for its repair. Carcinogenesis 1986;7:1849-51.

11 Troll $\mathbf{W}$, Wiesner $\mathbf{R}$. The role of oxygen radicals as a possible $\mathrm{V}$ mechanism of tumor promotion. Annual Review of Pharmat cology and Toxicology 1985;25:509-28.

12 Weitzman SA, Graceffa P. Asbestos catalyzes hydroxyl and superoxide radical generation from hydrogen peroxide. $A r c h$ Biochem Biophys 1984;228:373-6.

13 Eberhart MK, Roma'n-Franco AA, Quiles MR. Asbestos $\complement$ induced decomposition of hydrogen peroxide. Environ Res 1985;37:287-92.

14 Gulumian M, Van Wyk J. Hydroxyl radical production in thछ presence of fibres by a Fenton-type reaction. Chem Biol Intera 1987;62:89-97.

15 Zalma R, Bonneau L, Guignard J, Pezerat H, Jaurand M-CO Formation of oxy radicals by oxygen reduction arising from the surface activity of asbestos. Can J Chem 1987;65:2338-41.

16 Zalma R. Contribution a l'etude de la reactivite de surface des fibreß minerales. Relations possibles avec leurs proprietes cancerogenes Paris: Universite Pierre et Marie Curie, 1988. (Thesis.)

17 Leanderson P, Söderkvist P, Tagesson C, Axelson O, Formation of 8-hydroxydeoxyguanosine by asbestos and man-made mineral fibres. Br J Ind Med 1988;45:309-11.

18 Leanderson P, Söderkvist P, Tagesson C, Axelson O. Formation of the DNA adduct 8-hydroxydeoxyguanosine induced by man? made mineral fibres. In: Bartsch H, Hemminki K, O'Neill IK eds. Methods for detecting DNA damaging agents in humans ${ }^{\mathbb{D}}$ applications in cancer epidemiology and prevention. Lyon? International Agency for Research on Cancer, 1988:422-4음 (IARC sci publ 89.)

19 Kasai H, Nishimura S. Hydroxylation of deoxyguanosine at the $C$ 8 position by ascorbic acid and other reducing agents. Nucleic Acids Res 1984;12:2137-45.

20 Gregg SJ, Sing KS. Adsorption surface area and porosity. New York: Academic Press, 1967.

21 Weitzman SA, Weitberg AB. Asbestos-catalyzed lipid peroxidae tion and its inhibition by desferroxamine. Biochem $J$ 1985;225: $259-62$.

22 Floyd R, Watson JJ, Wong PK, Altmiller DH, Rickard RC: Hydroxyl free radical adduct of deoxyguanosine: sensitiv 0 detection and mechanism of formation. Free Radical Research Communication 1986;1:163-72.

23 Kasai $\mathbf{H}$, Nishimura S. DNA damage induced by asbestos in the presence of hydrogen peroxide. Gann 1984;75:841-4.

24 Valentine R, Chang MJW, Hart RW, Finch GL, Fisher GL? Thermal modification of chrysotile asbestos. Evidence foes decreased cytotoxicity. Environ Health Perspect 1983;51: 357-68.

25 Kuchino Y, Mori F, Kasai H, et al. Misreading of DNA templates containing 8-hydroxydeoxyguanosine at the modified base and at adjacent residues. Nature 1987;327:77-9.

26 Aida M, Nishimura S. An ab initio molecular orbital study on the characteristics of 8-hydroxyguanine. Mutat Res 1987;192:83-9. 